\title{
Energetic changes throughout early ontogeny of the brooding Antarctic sea star Rhopiella hirsuta (Koehler, 1920)
}

\author{
Sven Thatje ${ }^{1}\left[\right.$ [ Emma Steventon ${ }^{1} \cdot$ Olaf Heilmayer $^{1,2}$
}

Received: 23 August 2017 / Revised: 8 February 2018 / Accepted: 9 February 2018 / Published online: 24 February 2018

(c) The Author(s) 2018. This article is an open access publication

\begin{abstract}
An unusually high proportion of Antarctic echinoderms brood their young. Protection, reproductive constraints, low temperatures and limited food supply are all suggested motives for this reproductive pattern. This study looks at the reproductive energetics of the Antarctic asteroid Rhopiella hirsuta, and to establish the dynamics of feeding and elemental composition throughout its early juvenile development. Brooding females were analysed in terms of adult size, brood size and juvenile size with non-significant trends occurring with depth. Four brooding females were frozen straight after sampling and enabled the study of changes in elemental composition throughout embryo and early juvenile development with regard to their feeding mode. Morphological and elemental analyses indicate aseasonality of reproduction and lecithotrophic early ontogeny in this species. The most advanced juveniles found were significantly different from all earlier stages, with an increase in dry weight (DW) to $5.87( \pm 1.08) \mathrm{mg}$ suggesting growth, but a high C:N ratio of $8.60( \pm 0.59)$ that would indicate lecithotrophy. However, as the increase in DW was attributed to an increase in carbon, but not to an increase in nitrogen, it was not possible for the food source to be of organic origin.
\end{abstract}

Keywords Echinodermata $\cdot$ Asteroidea $\cdot$ Reproduction $\cdot$ Brood protection $\cdot$ Cold adaptation $\cdot$ Southern Ocean

\section{Introduction}

Echinoderms are amongst the most ubiquitous benthic animals and have been relatively well studied in both Antarctic shallow and deep seawaters from a reproductive point of view (Magniez 1983; Pearse and McClintock 1990; Bosch and Pearse 1990; Pearse et al. 1991). Brooding is suggested to have evolved at least fourteen times in echinoderms (Emlet 1990) with direct development of larvae thought to be rare due to the production of restrictive macro-evolutionary consequences (McEdward and Janies 1997), such as the low dispersal and high extinction rates in brooding species (Hansen 1983; Valentine and Jablonski 1983; Jablonski 1986).

It has long been known that a high proportions of Antarctic echinoderms brood their embryos (Thorson 1950;

Sven Thatje

svth@noc.soton.ac.uk

1 School of Ocean and Earth Science, National Oceanography Centre Southampton, University of Southampton, European Way, Southampton SO14 3ZH, UK

2 German Aerospace Centre, DLR, 53227 Bonn, Germany
Thatje et al. 2005; Gillespie and McClintock 2007; Pearse et al. 2009). For the 34 species of Antarctic asteroids for which reproductive patterns are known, 19 (56\% majority) produce non-pelagic larvae, almost exclusively by brooding (Pearse and Bosch 1994). Brooding is equally exemplified across a wide range of other Antarctic taxa including molluscs (Simpson 1977; Picken 1980; Hain and Arnaud 1992), and paracarideans (Heilmayer et al. 2008).

Reproduction in deep-sea Antarctic asteroids has been shown to occur on both seasonal and aseasonal cycles (Tyler et al. 1990, 1993) and environmental conditions common to both poles, e.g. low seawater temperature and salinity, short primary productivity, do both favour non-pelagic modes of development (Poulin et al. 2002). Pearse and Lockhart (2004) suggest that the predominance of brooding is not favoured by 'polar' conditions, but by the stability provided by the Antarctic Circumpolar Current (ACC), and that if pelagic larvae were produced they would be swept through Drake passage and lost, thus favouring non-pelagic development (Pearse and Bosch 1994; Pearse et al. 2009).

Antarctic echinoderms are known to be K-strategists (Clarke 1979) —a tradeoff between quantity and quality of offspring - as brooding is of high energetic cost and involves 
the production of large, slow-developing, nutrient-rich eggs (Steele and Steele 1975; Bosch and Slattery 1999), which often comes at the cost of reduced fecundity (Smith and Fretwell 1974). It is assumed that these eggs are sufficient to meet the metabolic requirement of development until individuals are capable of feeding externally (Shilling and Bosch 1994), with the primary energy source regarded as maternal yolk (Scott et al. 1990). Furthermore, it has been suggested that production of a large egg is due to the greater necessity of producing a larger, more advanced juvenile (Herring 1974; Strathmann and Strathmann 1982; Lawrence et al. 1984; Clarke 1992) that will have a greater chance of survival (Vance 1973) than to provide an increased energy resource to the developing embryo (McClintock and Pearse 1986). Maternal energy reserves supplied to the eggs provide them with an enhanced endotrophic potential (Anger and Schultze 1995) until they have developed a functional gut (McEdward and Janies 1993) and are capable of feeding on particulate matter (Shilling and Bosch 1994). This has been shown in other studies (Marsh et al. 1999; Bas et al. 2007) to be reflected in the $\mathrm{C}: \mathrm{N}$ ratios, as lipid decreases proportionately with development, signifying use of the maternal yolk by the embryo.

Here, we present an analysis of elemental composition and changes throughout the early ontogeny of the brooding Antarctic starfish Rhopiella hirsuta (Koehler, 1920) from around the Antarctic Peninsula. Results are discussed within the context of the physiological advantages of brooding in cold water.

\section{Materials and methods}

\section{Sampling}

Specimens of Rhopiella hirsuta were sampled by means of Agassiz trawl during expedition ANT XVIII/3 and ANT XXIII/8 of RV Polarstern in April 2000 and December 2006/January 2007, respectively (Table 1). Specimens were obtained from waters surrounding Elephant Island, the South Shetland Islands and Bransfield Strait (Tables 1, 2). After collection, eight specimens were bagged with their respective broods. Specimens were labelled alphabetically in order of analysis from A to $\mathrm{K}$ although females $\mathrm{B}, \mathrm{F}$, and $\mathrm{L}$ were subsequently discounted due to an absence of brooded juveniles. The samples were either frozen onboard at $-30^{\circ} \mathrm{C}$ or preserved in $4 \%$ buffered formalin-seawater solution.

\section{Biometry}

Frozen females were left to defrost at room temperature for about an hour. 10 randomly sampled replicate juveniles were removed from each of the four defrosted females and each arm length, as the distance (in $\mathrm{mm}$ ) from the centre of the disc to the tip of the arm was measured under a Leica $100 \mathrm{~mm} / 58 \mathrm{APO}$ microscope. Remaining juveniles were then removed from the female and counted (inclusive with the 10 previously removed) to determine the immediate brood size. Arm length of a further twenty juveniles selected haphazardly was measured to determine the average juvenile size per brood. Where the brood size was $<20$, all juveniles
Table 1 Locations and mode of collection of samples of Rhopiella hirsuta used in this study

\begin{tabular}{llllllll}
\hline Female & Area & Latitude $(\mathrm{S})$ & Longitude $(\mathrm{W})$ & Depth $(\mathrm{m})$ & Gear used & Action & Station \\
\hline A & EI & $61^{\circ} 03^{\prime} 19$ & $55^{\circ} 54^{\prime} 36$ & 187 & BT & Start trawl & $644-1$ \\
& EI & $61^{\circ} 01^{\prime} 78$ & $55^{\circ} 51^{\prime} 83$ & 149 & BT & End trawl & \\
B/C & EI & $60^{\circ} 53^{\prime} 00$ & $55^{\circ} 22^{\prime} 10$ & 307 & BT & Start trawl & $612-1$ \\
& EI & $60^{\circ} 52^{\prime} 61$ & $55^{\circ} 20^{\prime} 53$ & 482 & BT & End trawl & \\
D & SSI & $62^{\circ} 24^{\prime} 13$ & $61^{\circ} 24^{\prime} 06$ & 340 & BT & Start trawl & $680-1$ \\
& SSI & $62^{\circ} 22^{\prime} 50$ & $61^{\circ} 25^{\prime} 46$ & 336 & BT & End trawl & \\
E/F & EI & $60^{\circ} 52^{\prime} 37$ & $55^{\circ} 29^{\prime} 80$ & 248 & AGT & Start trawl & $614-3$ \\
& EI & $60^{\circ} 52^{\prime} 13$ & $55^{\circ} 30^{\prime} 31$ & 258 & AGT & End trawl & \\
G/H & BFS & $63^{\circ} 02^{\prime} 30$ & $59^{\circ} 10^{\prime} 40$ & 666 & GSN & Start trawl & $166-1$ \\
& BFS & $63^{\circ} 01^{\prime} 20$ & $59^{\circ} 09^{\prime} 20$ & 673 & GSN & End trawl & \\
I & EI & $61^{\circ} 20^{\prime} 35$ & $55^{\circ} 29^{\prime} 16$ & 151 & BT & Start trawl & $605-1$ \\
& EI & $61^{\circ} 19^{\prime} 98$ & $55^{\circ} 32^{\prime} 67$ & 145 & BT & End trawl & \\
J/K & EI & $61^{\circ} 20^{\prime} 33$ & $55^{\circ} 31^{\prime} 53$ & 137 & AGT & Start trawl & $605-3$ \\
& EI & $61^{\circ} 20^{\prime} 35$ & $55^{\circ} 30^{\prime} 18$ & 154 & AGT & End trawl & \\
\hline
\end{tabular}

Stations refer to those from the research cruises. All samples are from ANT XXIII/8 (Arntz and Brey 2001) except samples $\mathrm{G}$ and $\mathrm{H}$, which are from ANT XVIIl/3 (Gutt 2008)

EI Elephant Island, SSI South Shetland Islands, BFS Bransfield Strait, BT Bottom Trawl, AGT Agassiz trawl, GSN Bottom Trawl 


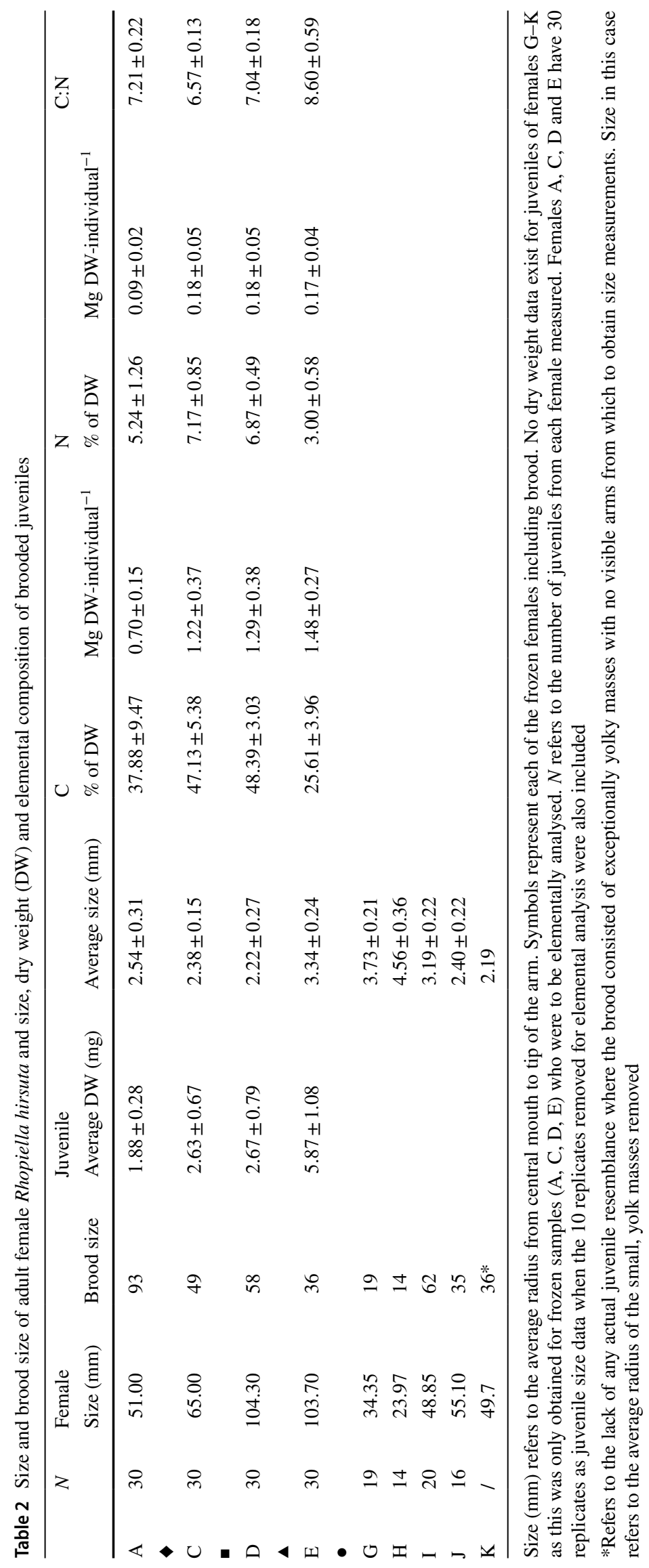


available were measured. All five arms from each juvenile were measured, but where rigidity of an arm curl restricted measurements, fewer arms were considered.

The adult female size was determined using the standard size methodology following Hopkins et al. (1994), i.e. measuring the distance from the tip of the arm to the mouth (the total radius) and the distance from the mouth to the intersect between two arms (central disc radius). Where females were restricted to the brood position, arm length was measured from the tip to the point of the bend and from the base of the brood chamber to the point of the bend. The central disc was measured from the aboral surface. Where female size is given in the text, it refers just to the total radius. The same procedure was followed for the formalin samples except that no juveniles were retained for elemental analysis.

\section{Juvenile biomass, elemental composition}

Ten juveniles from each of the four frozen females containing brood were sampled (as described in previous section) for subsequent determinations of dry weight (DW), carbon (C) and nitrogen $(\mathrm{N})$ following a modified protocol of Anger and Dawirs (1982). Briefly, juveniles were rinsed in ion free water, briefly blotted on filter paper and subsequently transferred to pre-weighed tin cartridges, and oven-dried for $48 \mathrm{~h}$ at $60{ }^{\circ} \mathrm{C}$. Samples were weighed to the nearest $0.1 \mu \mathrm{g}$ on a Sartorius M2P microbalance, to determine DW. C, N analyses were carried out with a Carlo Erba EA 1108 Elemental Analyzer using sulfurneromide as a standard. DW is given in absolute terms ( $\mu$ g per embryo), $\mathrm{C}$ and $\mathrm{N}$ data are given as mass-specific values (in percent of DW).

\section{Statistical analyses}

Tests for homogeneity were carried out on the $\mathrm{C}: \mathrm{N}$ ratios and results indicated two outliers, one from female $\mathrm{A}$ and one from female $\mathrm{C}$, which were subsequently eliminated and the results re-analysed. Kolmogorov-Smirnov tests confirmed the data to be normally distributed and following tests in statistics package Minitab to check the data fitted the four assumptions of analysis of variance, one-way ANOVAs were carried out on the following: (1) the average DW (mg) of 10 replicate juveniles from each of the frozen females (A, C, $\mathrm{D}$ and E), (2) the average DW of juveniles from females A, $\mathrm{C}$ and $\mathrm{D}$ as a result of finding those of female $\mathrm{E}$ to be significantly greater, (3) the five individual arm lengths of the 20 replicate juveniles measured from each female to determine the degree of variation within broods; and average arm lengths between each brood to determine the degree of variation among broods of different females, and (4) the average $\mathrm{C}: \mathrm{N}$ ratios of juveniles from each of the frozen females. Where average values are referred to in the text, these signify the arithmetic mean with \pm standard deviation (SD). Linear regression analyses were carried out to test for relationships of brood size with both adult female size and mean juvenile size, and a Chi-squared analysis was used to determine variation in brood sizes between females and in $\mathrm{C}: \mathrm{N}$ ratios of juveniles within the broods.

\section{Results}

\section{Female fecundity, juvenile morphology and asynchronous development}

A Chi-squared analysis proved that observed brood sizes do significantly depart from those expected of a homogenous distribution $\left(\chi_{8}^{2}=104.7, p<0.01\right)$. A large standard deviation of \pm 24.2 individuals indicates a high variability in brood size between the females. A non-significant but positive pattern can be observed between adult size and brood size $\left(R^{2}=0.07\right)$ (Fig. 1a) and a negative pattern exists between the mean juvenile size and brood size $\left(R^{2}=0.43\right)$ (Fig. 1b).

\section{Asynchrony in juvenile development}

Asynchrony in juvenile development with respect to arm length between all females is apparent (one-way ANOVA: $F_{7}=195.56, p<0.001$ ) (Table 3; Fig. 2). Of the frozen samples used for elemental analysis (females A-E), arm lengths of juveniles from female $\mathrm{E}$ are significantly longer than either A, C or D $\left(F_{3}=114.91, p<0.01\right)$. Significant differences are also apparent between the arm lengths of juveniles $\mathrm{A}, \mathrm{C}$ or $\mathrm{D}\left(F_{2}=11.83, p<0.001\right)$. In general, the developmental stage of juveniles advances with arm length, with juveniles from females G-I resembling adult morphology, whilst those from J, K and $\mathrm{L}$ appeared in much earlier stage of development, with a pentamerous morphology being largely absent. A yolk sac is still visible in such early stages.

\section{Asynchrony in juvenile size}

All broods exhibit asynchrony in juvenile size (Table 3), which is also reflected in the size class distribution of juveniles (Fig. 2). Highest within brood variability is found in female $\mathrm{H}$ with the most advanced juveniles but smallest brood size (Tables 2; Fig. 2).

\section{Dry weight, elemental composition}

Mean DW of juveniles is lowest in female A $(1.88 \mathrm{mg})$ and highest in female E (5.87 mg) (Table 2; Fig. 3). The variation in juvenile DW (indicated by SD (Table 2) within female broods is greatest for female $\mathrm{E}(\mathrm{SD} \pm 1.08)$ and 


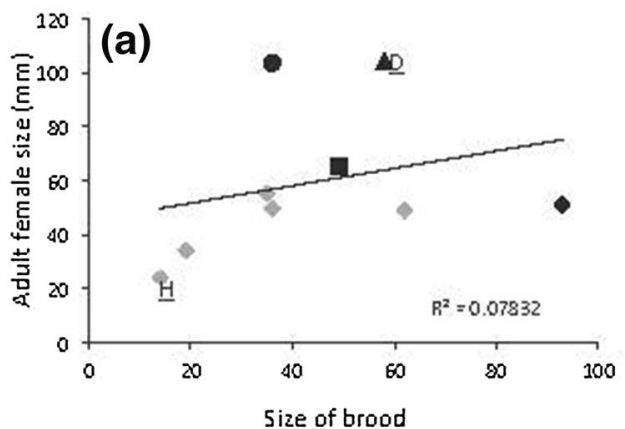

Fig. 1 Rhopiella hirsuta: a the relationship between female size and brood size; $\mathbf{b}$ the relationship between mean juvenile size and brood size. Trend lines show the linear regression with $R^{2}$ value. Black symbols refer to frozen females (cf Table 2); grey symbols refer to

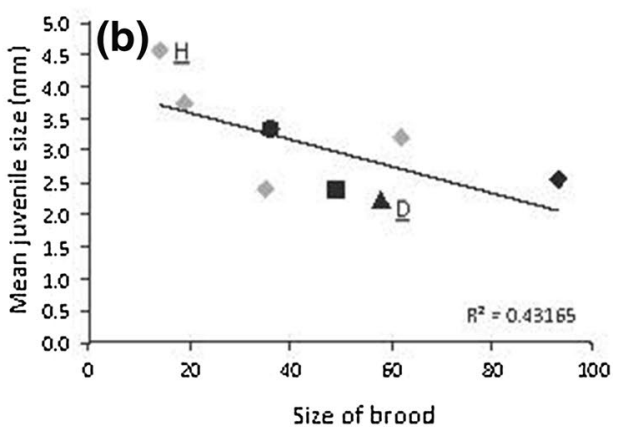

formalin-fixed individuals. Capital letters identify the female from which the juvenile came; $H$ smallest female at $23.97 \mathrm{~mm}$, with smallest brood size (4.56 $\mathrm{mm}$ arm length; $N=14), D$ largest female at $104.3 \mathrm{~mm}$, with smallest juveniles $(2.38 \mathrm{~mm}$ arm length; $N=58)$

Table 3 Minitab One-way ANOVA output for individual juvenile size within the brood of Rhopiella hirsuta

\begin{tabular}{lllllllll}
\hline & \multicolumn{2}{l}{ Brooding female } & & & \\
\cline { 2 - 8 } Output & $\mathrm{A}$ & $\mathrm{C}$ & $\mathrm{D}$ & $\mathrm{E}$ & $\mathrm{G}$ & $\mathrm{H}$ & $\mathrm{I}$ & $\mathrm{J}$ \\
\hline$P$ Value & $<0.001$ & $<0.001$ & $<0.001$ & $<0.001$ & $=0.005$ & $<0.001$ & $<0.001$ & $<0.001$ \\
$F$ value with (d.f.) & $(19), 22.57$ & $(19), 3.13$ & $(19), 11.12$ & $(19), 5.46$ & $(18), 2.81$ & $(13), 5.05$ & $(19), 4.46$ & $(15), 5.24$ \\
$R^{2}$ value (\%) & 84.28 & 42.68 & 72.54 & 56.44 & 61.29 & 70.08 & 55.83 & 62.56 \\
\hline
\end{tabular}

Degrees of freedom vary as measurements of some were restricted to just 2 or 3 out of the 5 arms. All primary data were included in one-way ANOVAS. With the exception of female $\mathrm{G}$, all results have $99 \%$ confidence limit

lowest for female A $(S D \pm 0.3)$ with variation within broods of females $\mathrm{C}$ and $\mathrm{D}$ being very similar (0.71 and 0.79 , respectively).

Like juvenile arm lengths, the mean DW of juveniles from female $\mathrm{E}$ was significantly greater than those of females A, C or $\mathrm{D}\left(F_{3}=53.42, p<0.01\right)$. A one-way ANOVA (excluding female $\mathrm{E}$ ) proved that the mean DW of juveniles from female A was significantly lower than juveniles from either females $\mathrm{C}$ or $\mathrm{D}\left(F_{2}=4.15, p<0.05\right)$.

Absolute carbon content decreases with advancing development, from juveniles of female $\mathrm{D}$, to $\mathrm{C}$ to $\mathrm{A}$, with the exception of juveniles from female $\mathrm{E}$, which show a steep increase in $\mathrm{C}$. The carbon content of female A juveniles is significantly lower than those of females C, D or E $\left(F_{3}=10.64, p<0.01\right)$. Carbon content of juveniles from female $\mathrm{E}$ increased by $112 \%$ from juveniles of female $\mathrm{A}$, to $1.48 \mathrm{mg} / \mathrm{C} / \mathrm{DW}$. The $\% \mathrm{C}$ content changes relative to developmental stage, with juveniles from female $\mathrm{D}$ having the highest (48.4\%) and juveniles from female $E$ having the lowest (25.6\%) (Fig. 3). Juveniles of female E have a significantly lower percentage $\mathrm{C}$ content that those of females $\mathrm{A}, \mathrm{C}$ or $\mathrm{D}$ $\left(F_{3}=31.54, p<0.01\right)$. In juveniles from females $\mathrm{A}, \mathrm{C}$ and $\mathrm{D}$, a greater \%C corresponds to an increase in DW, whilst in juveniles from female $\mathrm{E}$, the same response occurs to a decrease in $\% \mathrm{C}$.
Absolute $\mathrm{N}$ shows less fluctuation between the juveniles than $\mathrm{C}$ with a range of just $0.096 \mathrm{mg}$ (compared to $0.78 \mathrm{mg}$ for $\mathrm{C}$ ). $\mathrm{N}$ does not change relative to developmental stage like $\mathrm{C}$, although juveniles of female $\mathrm{E}$ and $\mathrm{A}$ (the two most advanced broods of the four) have the lowest absolute $\mathrm{N}$ ( 0.17 and $0.09 \mathrm{mg}$, respectively) with juveniles of female A again being significantly lower in $\mathrm{N}\left(F_{3}=7.98, p<0.01\right)$ than juveniles from either females $\mathrm{C}, \mathrm{D}$ or $\mathrm{E}$. The $\% \mathrm{~N}$ values are relatively consistent between juveniles of females $\mathrm{A}, \mathrm{C}$ and $\mathrm{D}$, ranging from 5.2 to $7.17 \%$ whilst the $\% \mathrm{~N}$ of juveniles from female $\mathrm{E}$ is significantly lower at $3 \%\left(F_{3}=50.61\right.$, $p<0.01)$.

Females with the most advanced broods (E and A) have the highest $\mathrm{C}: \mathrm{N}$ ratios and the two least developed (C and D) have the lowest. Juveniles of female $\mathrm{E}$ had a significantly higher C:N ratio than the other three $\left(F_{3}=37.35, p<0.01\right)$ and juveniles from female $\mathrm{C}$ had a significantly lower ratio than either those of females A or $\mathrm{D}\left(F_{2}=29.04, p<0.01\right)$. The $\mathrm{C}: \mathrm{N}$ ratio does not change proportionally to the changes in absolute values of $\mathrm{C}$ and $\mathrm{N}$. For example, juveniles of female D are on average $42 \%$ greater in terms of DW than juveniles of female A. They have $85 \%$ more C (mg DW) and $89 \%$ more $\mathrm{N}$ but the $\mathrm{C}: \mathrm{N}$ ratio is only $2 \%$ higher. However, a Chi-squared analysis of variation in $\mathrm{C}: \mathrm{N}$ within each brood proved to be non-significant $\left(\chi_{7}^{2}\right.$ test statistic $<15.507$ 
Fig. 2 Rhopiella hirsuta: size frequency distribution of juvenile sizes based on arm length $(\mathrm{mm})$. Layout is in the order of depth range of collection with shallowest. Note the different $y$-axis scales. Capital letter indicates female ID (cf Table 1) the left hand column being the
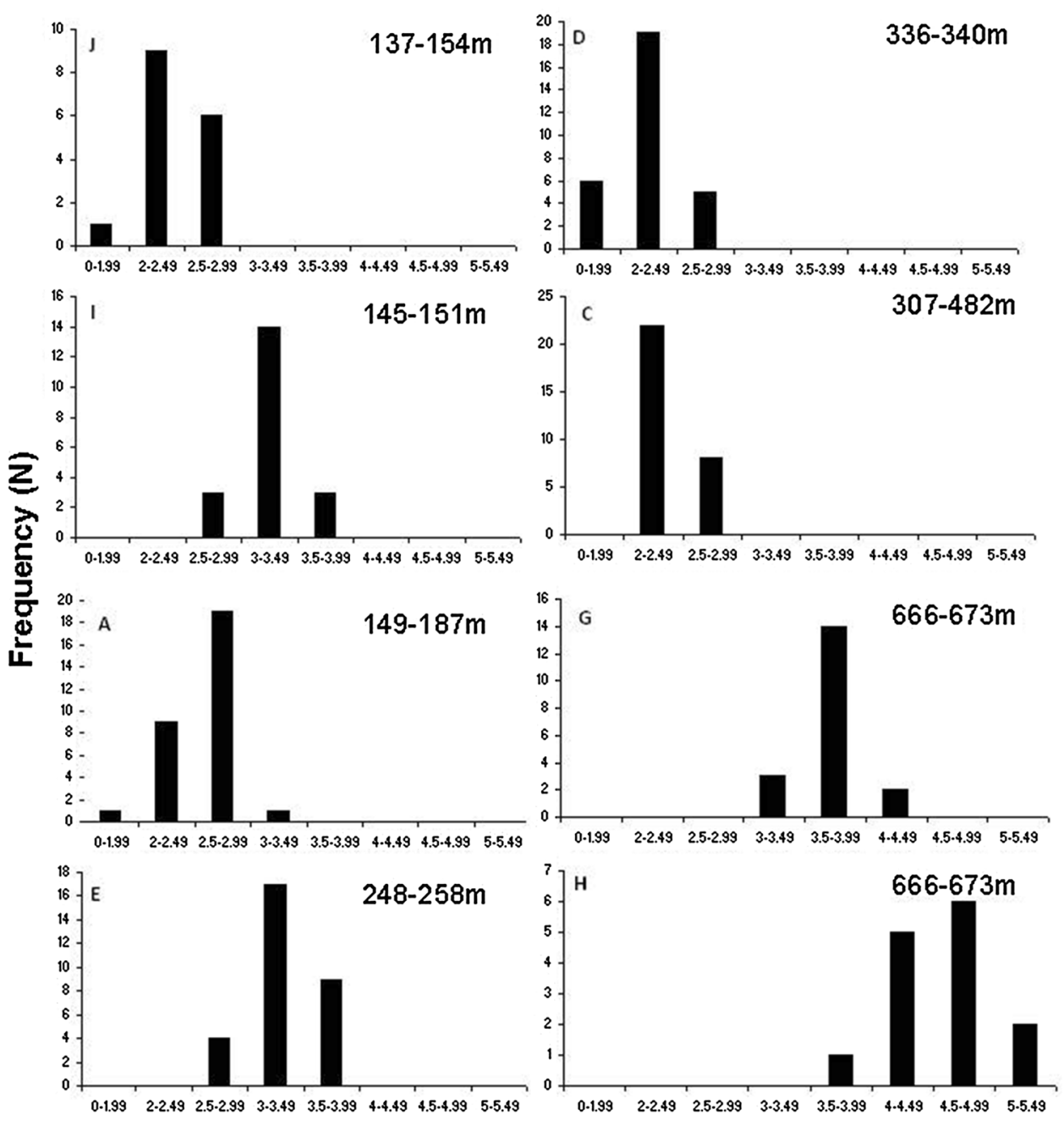

Size category $(\mathrm{mm})$

Fig. 3 Rhopiella hirsuta: changes in DW, mean arm length, $\mathrm{C}: \mathrm{N}$ ratio and elemental composition $(\mathrm{C}, \mathrm{N})$ throughout early juvenile development. The $\mathrm{x}$-axis letters D, C, A, E are the juveniles of females in order of developmental stage (cf Table 2)
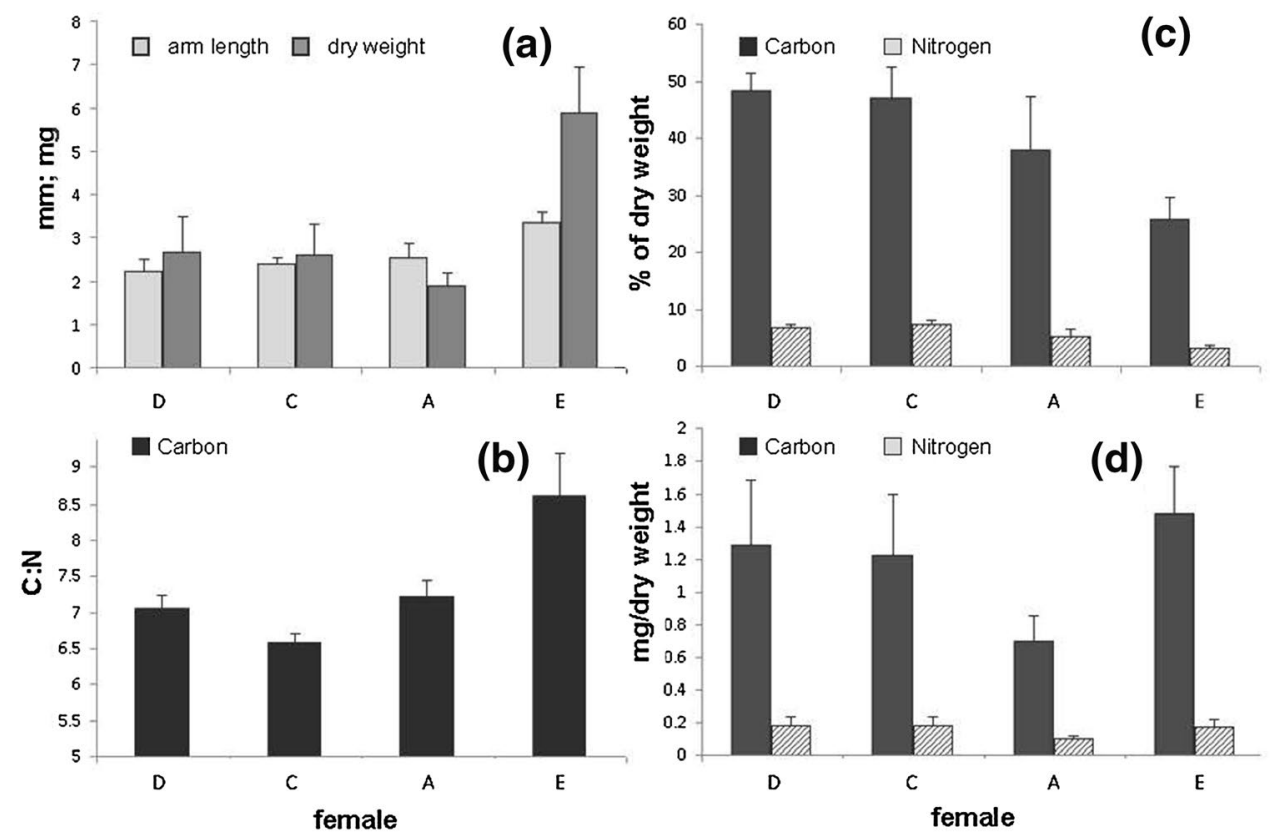
critical value). Regression analyses indicated that a highly significant $\left(R^{2}=0.87\right.$ and 0.79 , respectively) positive relationships existed between $\mathrm{C}: \mathrm{N}$ and mean juvenile size and mean juvenile DW, respectively.

\section{Bathymetric and spatial distribution}

All females sampled during southern summer were, geographically, within about $300 \mathrm{~km}$ of each other (Table 1) whilst their depth distribution spans a range of $212 \mathrm{~m}$. There is an apparent asynchrony in the development of offspring with depth, with females $\mathrm{G}$ and $\mathrm{H}$ from the deepest station (about $660 \mathrm{~m}$ ) possessing smallest brood size but largest juveniles, both in arm length and DW, and female A, the shallowest $(187 \mathrm{~m})$ of the frozen specimens, with largest brood size but lowest DW (Table 2). However, patterns of increasing arm length and $\mathrm{C}: \mathrm{N}$ ratio with depth (average depth of collection) are non-significant $\left(R^{2}=0.46\right.$ and 0.11 , respectively) and more data are needed to be able to fully address this question.

\section{Discussion}

\section{Female fecundity and brood dynamics}

Rhopiella hirsuta has been found down to the depths of $3845 \mathrm{~m}$ (Mah 2009), the deepest sample in this study being retrieved from $658 \mathrm{~m}$. Females $\mathrm{G}$ and $\mathrm{H}$ were the only ones to be sampled from Bransfield Strait, the most southerly of the sample sites $\left(63^{\circ} 04,50^{\prime} \mathrm{S}\right)$ whereas all other females came from waters off the South Shetland Islands, suggesting a possible (albeit small) latitudinal gradient in reproductive traits, with low fecundity and large juvenile size occurring at higher latitudes, as an adaptation to surviving the cold (for discussion see Thorson 1950; Lovrich et al. 2005; Heilmayer et al. 2008). However, data derived from our small sample size need to be treated with caution, and a review of Thorson's work by Pearse (1994) concluded that no latitudinal or depth trend in echinoderms with brooded development was apparent. Specimens were also obtained 3 months apart, which could attribute for developmental differences. Given the trends for fecundity and developmental stage observed but based on this limited dataset, a future large-scale study into this subject is desirable.

It appears that reproductive effort is geared towards a lower fecundity, but greater parental investment per offspring in deep waters. Progression into larger juvenile size is clearly exemplified in the size frequency distribution (Fig. 3) from $\sim 300 \mathrm{~m}$ and beyond. The size range of juveniles within the brood of the deepest female $(\mathrm{H})$ is greatest, possibly suggesting that in deeper waters, brooding females simultaneously brood their juveniles at slightly different sizes but in the same stage of development so as to stagger the requirement of her energy reserves in an environment with such limited food (Chia 1974). In terms of the juvenile, it is advantageous to brood in these highly oligotrophic waters (Rivkin 1991) as the responsibility of nutrient acquisition is with the brooding female and not the young juvenile, as is the case for planktotrophic larvae (Lawrence 1987).

Pearse and Bosch (1994) stated that brooding is not a consequence of limited food supply or of low temperatures affecting metabolic rate, but of the strong Bransfield Strait current, approximately $10 \mathrm{~km}$ wide with velocities up to $50 \mathrm{~cm} / \mathrm{sec}$ (Morozov 2007). It has the potential to remove any unprotected or pelagic larvae from the shallow shelf waters, and may occasionally transport them to new habitats. However, strong currents are not detrimental to all brooding taxa, for example, certain New Zealand sea urchins are facultative as opposed to obligate brooders, and developing embryos, if dislodged from the brood prior to calcification, would conclude their development as pelagic embryos/larvae (Pearse and Lockhart 2004).

\section{The seasonality of brooding}

In the present study, the analysed size frequency distribution of juveniles all fall into 2-3 adjacent categories indicating a fairly unimodal pattern within the broods. A single developmental stage within each brood is exhibited through a small range of juvenile sizes, highlighting the degree of within brood variation. From studies of the ophiuroid Amphiura carchara, Hendler (1991) described this brooding of just one development stage (as observed in this study) as 'sequential' brooding, which is said to occur when brood space is not limiting (Galley et al. 2005). Other organisms, such as the brooding bivalve Adacnarca nitens (Philobryidae) from the Ross Sea, exhibit simultaneous brooding of many different developmental stages at once, which allows for continuous recruitment to the population (Higgs et al. 2009). Gillespie and McClintock (2007) summarised that brooded echinoderm juveniles are initially the same size, but variability becomes apparent due to competition within the brood (see also Byrne 1996). The lowest within brood variation observed in the most advanced juveniles may be the cause of greatest exposure to competition in advanced broods, resulting in only the strongest and most competitive remaining. The fact that the standard deviations of individual size within the broods were similar for all broods, suggests that a certain degree of variability may be common in brooding invertebrates and that the significant variation in mean arm length from within the same brood could be due to differences in the individual's ability to adapt to the brooding environment, or it may simply be reflecting the ambiguity inherent in asteroid gametogenesis (McEdward and Carson 1987). Similarly, it has been previously documented that 
the process of oogenesis is slow in Antarctic echinoderms (Pearse et al. 1991), taking up to a year in some cases, thereby producing cohorts of oocytes growing at different stages. While it may be deemed a disadvantage for brooding to occur over the winter months due to higher metabolic cost and reduced food supply, some studies have shown larval metabolism to be so low that a high energy demand is unlikely (Hoegh-Guldberg and Manahan 1995). All different developmental stages observed among the broods of $R$. hirsuta, all of whom were collected at the same time of the year (between December 15th and January 2nd) confirm the hypothesis that reproduction is aseasonal and continuous.

\section{The metabolism of brooding}

Lawrence et al. (1984); see also McClary and Mladenov (1990) demonstrated that the energy content of brooded juveniles in Pteraster militaris is greater than that of eggs, therefore suggesting that the resources provided within the egg are insufficient to support growth to full term. In other words, what mechanisms are these juveniles employing to obtain a secondary supply of nutrients with which to fuel development? Although it seems likely that an external energy source is fuelling the growth in most advanced juveniles of $R$. hirsuta, lipid metabolism likely remains predominant and nitrogen does not increase proportionally to carbon. This suggests that it cannot be an organic substrate that fuelled the increase in DW, as protein synthesis is not occurring and that the substrate must therefore be one constituting inorganic carbon. It is unlikely that the elevated carbon observed in advanced juveniles is a result of the synthesis of lipid stores, as of yet, there is no evidence to suggest that benthic invertebrates are capable of producing such extensive wax esters, unless for use in reproduction (Ahn et al. 2003). For this reason, the increased carbon content cannot be attributed to either cannibalism or adelphophagy (Byrne 1996) as a simultaneous increase in the nitrogen component would also have been seen, as for example, in Gillespie and McClintock's (2007) study in which the embryo DW increased as a result of increased carbon and nitrogen. Equally, dissolved organic matter as an exogenous nutrient supply can also therefore be discounted. We therefore hypothesise that despite the limited dataset, the only plausible explanation for the high C:N ratio in these most advanced juveniles is the result of uptake of inorganic carbon.

Calcium carbonate, a requirement of all echinoderms for mineralisation of the exoskeleton (in the case of echinoids) and production of ossicles as part of the endoskeleton in asteroids (Knott 2004) is one such source of inorganic carbon that may be taken up by said juveniles. It is likely this endoskeleton which makes the advanced juveniles of female E more rigid and inflexible are those earlier stages of females
A, C or D. The sediments of the WAP shelf, from which these samples were taken, are subjected to strong periodic waves of phytodetritus following the retreat of winter sea ice (Mincks et al. 2005). It is suggested that this accumulating phytodetritus on the WAP shelf would become a persistent food bank for marine life and so it can be postulated that a persistent source of inorganic carbon will consequently also be available, thus fulfilling the newly endotrophic asteroid larvae's nutritional requirement.

Given the absence of traces of sediment in the stomachs of advanced juveniles, the question of how carbon is assimilated remains. Research has shown that embryos of certain echinoderms, such as sea urchins are capable of achieving net transport of organic compounds such as amino acids from seawater (Hultin 1952; Mitchison and Cummins 1966; Epel 1972) and this ability is said to increase as juveniles advance in order to meet increasing metabolic demands (Manahan et al. 1989). Although a clear answer remains subject to future study, it is indeed possible that embryos and juveniles of echinoderms are equally able to transport inorganic material into their tissues.

Acknowledgements We are grateful to the captain and crew of FS Polarstern for help and assistance at sea.

Funding This work was supported by the European Commission through the Marine Biodiversity and Ecosystem Functioning Network of Excellence MarBEF of the FP6 (Contract No. GOCE-CT-2003-505446).

\section{Compliance with ethical standards}

Conflict of interest The authors declare that they have no conflict of interest.

Ethical approval All applicable international, national, and/or institutional guidelines for the care and use of animals were followed.

Open Access This article is distributed under the terms of the Creative Commons Attribution 4.0 International License (http://creativeco mmons.org/licenses/by/4.0/), which permits unrestricted use, distribution, and reproduction in any medium, provided you give appropriate credit to the original author(s) and the source, provide a link to the Creative Commons license, and indicate if changes were made.

\section{References}

Ahn IY, Surh J, Park YG, Kwon H, Choi KS, Kang SH, Choi HJ, Kim KW, Chung H (2003) Growth and seasonal energetics of the Antarctic bivalve Laternula elliptica from King George Island, Antarctica. Mar Ecol Prog Ser 257:99-110

Anger K, Dawirs RR (1982) Elemental composition (C, N, H) and energy in growing and starving larvae of Hyas araneus (Decapoda, Majidae). Fish Bull 80:419-433 
Anger K, Schultze K (1995) Elemental composition (CHN), growth and exuvial loss in the larval stages of two semiterrestrial crabs, Sesarma curacaoense and Armases miersii (Decapoda: Grapsidae). Comp Biochem Phys A 111:615-623

Arntz WE, Brey T (2001) The expedition ANTARKTIS XVIIl3 (EASIZ III) of the research vessel POLARSTERN in 2000. Berichte Polar Meeresforsch 402:198

Bas CC, Spivak ED, Anger K (2007) Seasonal and interpopulational variability in fecundity, egg size, and elemental composition (CHN) of eggs and larvae in a grapsoid crab, Chasmagnathus granulatus. Helgol Mar Res 61:225-237

Bosch I, Pearse JS (1990) Developmental types of shallow water asteroids of McMurdo Sound, Antarctica. Mar Biol 104:41-46

Bosch I, Slattery M (1999) Costs of extended brood protection in the Antarctic sea star, Neosmilaster georgianus (Echinodermata: Asteroidea). Mar Biol 134:449-459

Byrne M (1996) Viviparity and intragonadal cannibalism in the diminutive sea stars Patiriella vivipara and $P$. parvivipara (Family Asterinidae). Mar Biol 125:551-567

Chia FS (1974) Classification and adaptative significance of developmental patterns in marine invertebrates. Thalass Jugoslav $10: 121-130$

Clarke A (1979) On living in cold water: K-strategies in Antarctic benthos. Mar Biol 55:111-119

Clarke A (1992) Reproduction in the cold: thorson revisited. Invertebr Reprod Dev 22:175-184

Emlet RB (1990) World patterns of developmental mode in echinoid echinoderms. In: Hoshi M, Yamashita O (eds) Advances in invertebrate reproduction, vol 5. Elsevier, Amsterdam, pp 329-335

Epel D (1972) Activation of an $\mathrm{Na}^{+}$-dependent amino acid transport system upon fertilization of sea urchin eggs. Exp Cell Res 72:74-89

Galley EA, Tyler PA, Clarke A, Smith CR (2005) Reproductive biology and biochemical composition of the brooding echinoid Amphipneustes lorioli on the Antarctic continental shelf. Mar Biol 148:59-71

Gillespie JM, McClintock JB (2007) Brooding in echinoderms: how can modern experimental techniques add to our historical perspective? J Exp Mar Biol Ecol 342(2):191-201

Gutt J (2008) The expedition ANTARKTIS-XXIII/8 of the research vessel "Polarstern" in 2006/2007. Rep Polar Mar Res 569:1-153

Hain S, Arnaud PM (1992) Notes on the reproduction of high-Antarctic molluscs from the Weddell Sea. Polar Biol 12:303-312

Hansen TA (1983) Modes of larval development and rates of speciation in early Tertiary neogastropods. Science 220:501-502

Heilmayer O, Thatje S, McClelland C, Conlan K, Brey T (2008) Changes in biomass and elemental composition during early ontogeny of the Antarctic isopod crustacean Ceratoserolis trilobitoides. Polar Biol 31:1325-1331

Hendler G (1991) Echinodermata: Ophiuroidea. In: Giese AC, Pearse JS, Pearse VB (eds) Reproduction of marine invertebrates, vol VI. Boxwood Press. Pacific Grove, California, pp 356-513

Herring PJ (1974) Size, density and lipid content of some decapod eggs. Deep-Sea Res 21:91-94

Higgs ND, Reed AJ, Hooke R, Honey DJ, Heilmayer O, Thatje S (2009) Growth and reproduction in the brooding Antarctic bivalve, Adacnarca nitens (Phylobridae) from the Ross Sea. Mar Biol 156:1073-1081

Hoegh-Guldberg O, Manahan DT (1995) Coulometric measurement of oxygen consumption during development of marine invertebrate embryos and larvae. J Exp Mar Biol Ecol 198:19-30

Hopkins TS, Watts S, McClintock JB, Marion KR (1994) Contrasting size demographics, sub-lethal arm loss and arm regeneration in two populations of Astropecten articulatus (Say) in the northern
Gulf of Mexico. In: Guille D, Fèral JP, Roux M (eds) Echinoderms through time. Balkema, Rotterdam, p 311

Hultin T (1952) Incorporation of ${ }^{15} \mathrm{~N}$-labeled glycine andalanine into the proteins of developing sea urchin eggs. Exp Cell Res 3:494-501

Jablonski D (1986) Larval ecology and macroevolution in marine invertebrates. Bull Mar Sci 39:565-587

Knott E (2004) Asteroidea, seastars and starfishes, version 07, October 2004. http://tolweb.org/asteroidea/19238/2004.10.07. In: the tree of life web project, http://tolweb.org

Lawrence JM (1987) A functional biology of echinoderms. Johns Hopkins University Press, Baltimore, p 340

Lawrence JM, McClintock JB, Guille A (1984) Organic level and caloric content of eggs of brooding asteroids and an echinoid (Echinodermata) from Kerguelen (South-Indian Ocean). Int J Invertebr Reprod 7:249-257

Lovrich GA, Romero MC, Tapella F, Thatje S (2005) Distribution, reproductive and energetic conditions of decapod crustaceans along the Scotia Arc (Southern Ocean). Scient Mar. 69(Suppl 2):183-193

Magniez P (1983) Reproductive cycle of the brooding echinoid Abatus cordatus (Echinodermata) in Kerguelen (Antarctic Ocean): changes in the organ indices, biochemical composition and caloric content of the gonads. Mar Biol 74:55-64

Mah C (2009) Rhopiella hirsuta (Koehler, 1920). World asteroidea database CMAR c-squares Xplanet mapper V1.0.2 (www.iobis .org). Accessed 20 July 2017 from the world register of marine species at http://www.marinespecies.org/aphia.php? $\mathrm{p}=$ taxdetails $\& \mathrm{id}=172745$

Manahan DT, Jaeckle WB, Nourizadeh SN (1989) Ontogenic changes in the rates of amino acid transport by marine invertebrate larvae. Biol Bull 176:161-168

Marsh AG, Leong PKK, Manahan DT (1999) Energy metabolism during embryonic development and larval growth of an Antarctic sea urchin. J Exp Mar Biol 202:2041-2050

McClary DJ, Mladenov PV (1990) Brooding biology of the seastar Pteraster militaris (Mueller, O.F.) —energetic and histological evidence for nutrient translocation to brooded juvenies. J Exp Mar Biol Ecol 142:183-199

McClintock JB, Pearse JS (1986) Organic and energetic content of eggs and juveniles of Antarctic echinoids and asteroids with lecithotrophic development. Comp Biochem Phys A 85(2):341-345

McEdward LR, Carson SF (1987) Variation in egg organic content and its relationship with egg size in the starfish Solaster stimpsoni. Mar Ecol Prog Ser 37:159-169

McEdward LR, Janies DA (1993) Life cycle evolution in asteroids: what is a larva? Biol Bull 184:255-268

McEdward LR, Janies DA (1997) Relationships among development, ecology and morphology in the evolution of echinoderm larvae and life cycles. Biol J Linn Soc 60:1-40

Mincks SL, Smith CR, DeMaster DJ (2005) Persistence of labile organic matter and microbial biomass in Antarctic shelf sediments: evidence of a sediment "food bank". Mar Ecol Prog Ser 300:3-19

Mitchison JM, Cummins JE (1966) The uptake of valine and cytidine by sea urchin embryos and its relation to the cell surface. J Cell Sci 1:35-47

Morozov EG (2007) Currents in Bransfield Strait. Doklady Earth Sci 415(6):684-686

Pearse JS (1994) Cold-water echinoderms break "Thorson's rule'. In: Eckelbarger KJ, Young CM (eds) Reproduction, larval biology, and recruitment in the deep-sea benthos. Columbia University Press, New York, pp 26-39

Pearse JS, Bosh I (1994) Brooding in the Antarctic: Ostergren had it nearly right. In: David B, Guille A, Féral JP, Roux M (eds) Echinoderms through time. Balkema, Rotterdam, pp 111-120 
Pearse JS, Lockhart SJ (2004) Reproduction in cold water: paradigm changes in the 20th century and a role for cidaroid urchins. DeepSea Res II 51:1533-1549

Pearse JS, McClintock JB (1990) A comparison of reproduction by the brooding spatangoid echinoids Abatus shackletoni and A. nimrodi in McMurdo Sound, Antarctica. Invertebr Reprod Dev 17:181-191

Pearse JS, McClintock JB, Bosch I (1991) Reproduction of Antarctic benthic marine invertebrates: tempos, modes and timing. Am Zool 31:65-80

Pearse JS, Mooi R, Lockhart SJ, Brandt A (2009) Brooding and species diversity in the Southern Ocean: selection for brooders or speciation within brooding clades? Smithsonian at the poles: contributions to international polar year science-a Smithsonian contribution to knowledge, pp 181-196

Picken GB (1980) Reproductive adaptations of Antarctic benthic invertebrates. Biol J Linn Soc 14:67-75

Poulin E, Palma AT, Féral JP (2002) Evolutionary versus ecological success in Antarctic benthic invertebrates. Trends Ecol Evol $17: 218-222$

Rivkin RB (1991) Seasonal patterns of planktonic production McMurdo Sound, Antarctica. Am Zool 31:5-16

Scott LB, Leahy PL, Decker GL, Lennarz WJ (1990) Loss of yolk platelets and yolk glycoproteins during larval development of the sea urchin embryo. Dev Biol 137:368-377

Shilling FM, Bosch I (1994) 'Pre-feeding' embryos of Antarctic and temperate echinoderms use dissolved organic material for growth and metabolic needs. Mar Ecol Prog Ser 109:173-181
Simpson RD (1977) The reproduction of some littoral molluscs from Macquarie Island (Sub-Antarctic). Mar Biol 44:125-142

Smith CC, Fretwell SD (1974) The optimal balance between size and number of offspring. Am Nat 108:499-506

Steele DH, Steele VJ (1975) Egg size and duration of embryonic development in Crustacea. Int Rev Ges Hydrobiol 60:711-715

Strathmann RR, Strathmann MF (1982) The relationship between adult size and brooding in marine invertebrates. Am Nat 119:91-101

Thatje S, Hillenbrand CD, Larter R (2005) On the origin of Antarctic marine benthic community structure. Trends Ecol Evol 20:534-540

Thorson G (1950) Reproductive and larval ecology of marine bottom invertebrates. Biol Rev 25:1-45

Tyler PA, Billett DSM, Gage JD (1990) Seasonal reproduction in the sea star Dytaster grandis from $4000 \mathrm{~m}$ in the northeast Atlantic Ocean. J Mar Biol Assoc UK 70:173-180

Tyler PA, Gage JD, Paterson GJL, Rice AL (1993) Dietary constraints on reproductive periodicity in two sympatric deep-sea astropectinid seastars. Mar Biol 115:267-277

Valentine JW, Jablonski D (1983) Larval adaptations and patterns of brachiopod diversity in space and time. Evolution 37:1052-1061

Vance RR (1973) On reproductive strategies in marine benthic invertebrates. Am Nat 107:339-352 